\title{
Uptake of Gentamicin by Bullfrog Saccular Hair Cells in vitro
}

\author{
P.S. Steyger, ${ }^{1}$ S.L. Peters, ${ }^{1}$ J. Rehling, ${ }^{1}$ A. Hordichok, ${ }^{1}$ and C.F. Dai ${ }^{1,2}$ \\ ${ }^{1}$ Oregon Hearing Research Center, Oregon Health $\mathcal{E}$ Science University, Portland, OR, 97201, USA \\ ${ }^{2}$ Department of Otolaryngology, Eye Ear Nose and Throat Hospital, Fudan University, Shanghai, 200031, P.R. China
}

Received: 24 January 2003; Accepted: 2 July 2003; Online publication: 12 November 2003

\section{ABSTRACT}

Vertebrate sensory hair cells in the inner ear are pharmacologically sensitive to aminoglycoside antibiotics. Although the ototoxicity of aminoglycosides is well known, the route of drug uptake by hair cells and mechanisms of cytotoxicity remain poorly understood. Previously published studies have documented the intracellular distribution of gentamicin using immunocytochemical, electron microscopic, and autoradiographic methods. In this article, we compare the subcellular distribution of fluorescently conjugated gentamicin (gentamicin-Texas Red, GTTR) with immunolabeled gentamicin using confocal or electron microscopy. Gentamicin (detected by postfixation immunocytochemistry) and GTTR were rapidly taken up by hair cells throughout the bullfrog saccular explant in vitro and preferentially in peripheral hair cells. Immunolabeled gentamicin and GTTR were observed at the apical membranes of hair cells, particularly in their hair bundles. GTTR was also identified within a variety of subcellular compartments within hair cells, including lysosomes, mitochondria, Golgi bodies, endoplasmic reticulum, and nuclei, and in similar structures by immunoelectron microscopy. The distributions of GTTR and immunolabeled gentamicin are largely identical and corroborate a variety of published immunocytochemical and autoradiography studies. Thus, GTTR is a valid fluorescent probe with which to investigate the pharmacokinetics and mechanisms of gentamicin accumulation.

\footnotetext{
Correspondence to: P.S. Steyger, Ph.D. Oregon Hearing Research Center, NRC $0413 \cdot$ Oregon Health \& Science University $\cdot 3181$ Sam Jackson Park Road • Portland, OR 97239 • Telephone: 503-494-1062; fax: 503-494-5656; email: steygerp@ohsu.edu
}

Keywords: gentamicin, hair cells, drug accumulation, endocytosis, ototoxicity

\section{INTRODUCTION}

Gentamicin is a positively charged aminoglycoside antibiotic that is selectively toxic to inner ear sensory hair cells (Miller 1985) and kidney proximal tubule cells (Humes 1999). Gentamicin is used clinically to treat life-threatening, Gram-negative bacterial infections (e.g., meningitis), to prevent infection in patients with severe burns or large wound injuries, and also in premature babies. However, serious nephrotoxic and ototoxic side effects can occur when aminoglycosides are used clinically (Barza and Lauermann 1978; Lerner and Matz 1979).

Although serum clearance of aminoglycosides is rapid $(<24 \mathrm{~h})$, both proximal tubule cells and hair cells preferentially accumulate and retain aminoglycosides. The most-investigated mechanism of aminoglycoside uptake has been endocytosis, followed by lysosomal processing (Humes 1988; Hashino et al. 1997, 2000; Molitoris 1997; Sandoval et al. 1998, 2000). In hair cells, aminoglycosides have long halflives (5-6 months) and are poorly degraded (Dulon et al. 1993; Imamura and Adams 2003b). Autoradiography of tritiated gentamicin and immunocytochemical methods have revealed the intracellular distribution of gentamicin following fixation, but these methods cannot be used to follow uptake of gentamicin by living cells in real-time. A fluorescent probe was conjugated to gentamicin to enable the 
same probe to be used for both: (1) high-resolution confocal microscopy of intracellular distribution in fixed surface preparations and (2) pharmacokinetics of gentamicin accumulation by living cells. Furthermore, a fluorescently conjugated gentamicin will have less regulatory and environmental impact than radiolabeled substances. In this article, we compare the subcellular distribution of fluorescently conjugated gentamicin (gentamicin-Texas Red, GTTR) with that for immunolabeled gentamicin in bullfrog saccular hair cells in vitro. Demonstrating that the subcellular locations of GTTR are similar to that for immunolabeled gentamicin is essential prior to determining the potential utility of GTTR for pharmacokinetic investigations of gentamicin accumulation and distribution.

\section{METHODS}

Gentamicin sulfate (Sigma, St. Louis, MO; $50 \mathrm{mg} / \mathrm{ml}$ in $\mathrm{K}_{2} \mathrm{CO}_{3}, \mathrm{pH} 9$ ) and succinimidyl esters of Texas Red (Molecular Probes, Eugene, OR; $2 \mathrm{mg} / \mathrm{ml}$ in dimethyl formamide) were agitated together overnight to produce a gentamicin-Texas red conjugate (GTTR). Typically, $4.4 \mathrm{ml}$ of $50 \mathrm{mg} / \mathrm{ml}$ (final volume) gentamicin sulfate (GT) was mixed with $0.6 \mathrm{ml}$ of $2 \mathrm{mg} / \mathrm{ml}$ Texas Red (TR) esters to produce an approximately 300:1 molar ratio of GT:GTTR. A high ratio of free gentamicin to TR esters ensures a minimum of unbound TR molecules, and a binding ratio of 1 TR molecule to 1 GT molecule (Sandoval et al. 1998). Gentamicin sulfate has three isoforms with molecular weights of (C1) 449.5, (C2) 463.5, and $\left(\mathrm{Cl}_{\mathrm{a}}\right)$ 477.6. Texas Red succinimidyl esters have a molecular weight of 817 . When combined, the conjugates have (rounded) molecular weights of 1165 , 1179 , 1193, respectively, after loss of the carbonyl amine from the reactive TR. Gentamicin has 3 or 4 amine groups depending on the isoform, and the conjugation of a TR molecule to a gentamicin amine group reduces the ionic charge of the conjugated molecule by one for each amine group conjugated to TR (generally one), proportionately increasing its hydrophobicity. After conjugation, the GTTR conjugate is typically still a polyamine and a polycation.

\section{Saccule explanation}

Bullfrogs (Rana catesbeiana) were anesthetized with $0.2 \%$ MS-222 and chilled before decapitation. The temporal bones were excised in cold oxygenated HEPES-buffered saline (HBS) containing $110 \mathrm{mM}$ $\mathrm{Na}^{+}, 2 \mathrm{mM} \mathrm{K}{ }^{+}, 4 \mathrm{mM} \mathrm{Ca}{ }^{2+}, 120 \mathrm{mM} \mathrm{Cl}^{-}, 3 \mathrm{mM} \mathrm{D}-$ glucose, and $5 \mathrm{mM}$ HEPES (pH 7.25; $220 \mathrm{mOsm}$ ). Each saccule was isolated and the otolithic membrane removed by proteolytic digestion for 20 minutes in oxygenated $50 \mu \mathrm{g} / \mathrm{ml}$ subtilopeptidase BPN (Sigma) at room temperature. Saccular explants were then incubated in Wolf-Quimby culture medium (containing $1 \mathrm{mM} \mathrm{Ca}^{2+}$; Life Technologies, Carlsbad, CA) supplemented with $100 \mu \mathrm{g} / \mathrm{ml}$ ciprofloxacin in a $5 \%$ $\mathrm{CO}_{2}$ environment at $25^{\circ} \mathrm{C}$ (Steyger et al. 19971998). Gentamicin-treated explants were incubated in the above culture media, supplemented with $300 \mu \mathrm{g} / \mathrm{ml}$ GT/GTTR. The Institutional Animal Care and Use Committee of Oregon Health \& Science University approved these procedures.

\section{Confocal microscopy}

For confocal microscopy, excised saccular explants were individually preloaded (for $40 \mathrm{~min}$ ) with $50 \mathrm{nM}$ MitoTracker, $50 \mathrm{nM}$ Lysotracker Green, $1 \mu \mathrm{M}$ NBDceramide, or $1 \mu \mathrm{M}$ ERtracker (Molecular Probes) in Wolfe-Quimby amphibian culture media to label mitochondria, lysosomes, Golgi bodies, or endoplasmic reticulum, respectively, prior to incubation with 300 $\mu \mathrm{g} / \mathrm{ml} \mathrm{GT} / \mathrm{GTTR}$ for $2 \mathrm{~h}$. Explants were either (1) fixed in $4 \%$ formaldehyde (MitoTracker Green- and Lysotracker Green-loaded explants) and mounted, or (2) placed in chambered coverslips and directly observed live (NBD-ceramide- and ERtracker-loaded explants), using a Bio-Rad MRC 1024 ES laser scanning confocal system attached to a Nikon Eclipse TE300 inverted microscope. For immunocytochemistry of gentamicin, explants were incubated with 300 $\mu \mathrm{g} / \mathrm{ml}$ unconjugated gentamicin for $30 \mathrm{~min}$ or $2 \mathrm{~h}$, fixed, ice-cold acetone-permeabilized, and processed for indirect fluorescence immunocytochemistry. Explants were immunoblocked with $10 \%$ horse serum and $1 \%$ bovine serum albumin (BSA) in $0.02 \mathrm{M}$ PBS for $30 \mathrm{~min}$ and incubated with antigentamicin antibodies (American Qualex, San Clemente, CA) overnight. After washing in $1 \%$ BSA-PBS, explants were incubated in Alexa-568-conjugated goat antirabbit secondary antibodies. Subsequently, organs were labeled with Alexa-660-conjugated phalloidin and/or Sytox Green (Molecular Probes), prior to mounting in VectaShield (Vector Laboratories, Burlingame, CA) and confocal imaging. Immunocytochemical controls included: (1) primary antibody labeling of saccular explants incubated with normal culture media only, and (2) gentamicin-adsorbed primary antibody labeling of GT-treated explants. Confocal images of double-labeled specimens were collected sequentially to prevent bleed-through and cross-talk between the different fluorescent probes, using a $\times 60$ [numerical aperture (N.A.) 1.4] objective lens in $1024 \times 1024$ pixel frames with an $x y$ resolution $=240 \mathrm{~nm}$ and $x z$ resolution $=400 \mathrm{~nm}$, and post-processed using the Bio-Rad LaserSharp imaging software. Colocalization 
TABLE 1

Theoretical and observed $x y$ and z-axis resolution for Bio-Rad MRC 1024 confocal system with a Nikon TE300 microscopes

\begin{tabular}{|c|c|c|c|c|c|}
\hline \multirow[b]{2}{*}{$\begin{array}{c}\text { Oil immersion } \\
\text { objective }\end{array}$} & \multirow[b]{2}{*}{$\begin{array}{c}\text { Theoretical } \\
\text { xy resolution }{ }^{a}(\mathrm{~nm})\end{array}$} & \multicolumn{2}{|c|}{$512 \times 512$} & \multicolumn{2}{|c|}{$1024 \times 1024$} \\
\hline & & $\begin{array}{c}\text { Pixel } \\
\text { size }(n m)\end{array}$ & $\begin{array}{l}\text { Observed } \\
\text { resolution }(\mathrm{nm})\end{array}$ & $\begin{array}{c}\text { Pixel } \\
\text { size }(n m)\end{array}$ & $\begin{array}{l}\text { Observed } \\
\text { resolution }(\mathrm{nm})\end{array}$ \\
\hline $40 \times($ N.A. 1$)$ & 257.5 & 474 & 490 & 237 & 350 \\
\hline $40 \times+$ zoom & 257.5 & 200 & 280 & 100 & 260 \\
\hline $60 \times($ N.A. 1.4$)$ & 184 & 316 & 330 & 158 & 230 \\
\hline $60 x+$ zoom & 184 & 100 & 230 & 100 & 230 \\
\hline & Theoretical $x z$ resolution $^{b}(\mathrm{~nm})$ & & & Pixel size $(\mathrm{nm})$ & Observed resolution $(\mathrm{nm})$ \\
\hline $40 \times+$ zoom & 390.1 & & & 100 & 600 \\
\hline $60 x+$ zoom & 199 & & & 100 & 230 \\
\hline
\end{tabular}

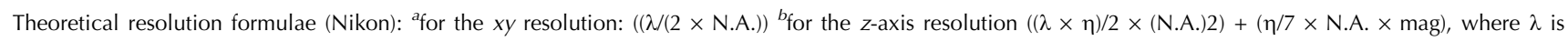
wavelength $(515 \mathrm{~nm}), \eta$ is immersion oil refractive index (1.515); N.A. is numerical aperture, and mag. is magnification.

analysis was performed only on individual optical sections within a focal series. Pixels containing both red (e.g., GTTR or immunolabeled GT) and blue (phalloidin-Alexa-660) or green (Sytox Green) intensities above a user-defined threshold appeared as white within a colorized merged image for each optical section, indicating which pixels were sites of colocalization of the two chosen fluorophores.

\section{Resolution of the confocal microscopy system}

To determine the observed $x y$ resolution for the BioRad MRC 1024 confocal system attached to a Nikon TE300 microscope, subresolution fluorescent beads (0.175 $\mu \mathrm{m}$; Molecular Probes) mounted under 1.5 coverslips were imaged, and the full-width half-maximum (FWHM) of several fluorescent specks was obtained for each lens used. The observed z-axis resolution was obtained by blue reflection imaging of an ultrathin sputter-coated coverslip $(<30 \mathrm{~nm})$ to subsequently obtain the FWHM (Pawley 1995). The FWHM is derived from a line intensity graph of the subresolution target, where the observed optical resolution equals the width between the two slopes, approximately halfway between baseline and peak fluorescence of a subresolution fluorescent bead. The $y$-coordinate is derived using the following equation:

$$
\left(\left(F_{\max }-F_{\mathrm{bkg}}\right) / 2\right)+F_{\mathrm{bkg}}
$$

Therefore, the optical resolution (in $\mu \mathrm{m}$ ) is $x$-coordinate of Slope $2-x$-coordinate of Slope 1 (Pawley 1995).

\section{Immuno-electron microscopy}

Saccular explants were incubated with $300 \mu \mathrm{g} / \mathrm{ml}$ unconjugated GT for $2 \mathrm{~h}$ prior to washing and fixa- tion in $4 \%$ paraformaldehyde plus $0.5 \%$ glutaraldehyde in $0.1 \mathrm{M}$ phosphate buffer for $2 \mathrm{~h}$. Samples were dehydrated through an ascending alcohol series at progressively lower temperatures, culminating at $-40^{\circ} \mathrm{C}$. Subsequently, samples were infiltrated with LR Gold over $72 \mathrm{~h}$ and polymerized with UV light for $48 \mathrm{~h}$ using the Leica AFS low-temperature embedding system. Ultrathin sections were obtained on an ultramicrotome, collected on nickel grids, and passaged several times through distilled water and subsequently several times with $5 \mathrm{mM}$ Tris (TBS). Grids were then immunoblocked with $20 \%$ normal goat serum in TBS for $30 \mathrm{~min}$ and incubated overnight with gentamicin antibodies in $1 \%$ BSA/TBS at $4^{\circ} \mathrm{C}$. Grids were rinsed three times in TBS and incubated in gold-labeled secondary antibodies $(15 \mathrm{~nm}$ gold particles conjugated to goat antirabbit IgG, diluted 1:100; Ted Pella) in 1\% BSA in TBS for $1 \mathrm{~h}$. Immunocytochemical controls included (i) replacing primary antibodies with gentamicin-adsorbed primary antibodies, or (ii) primary antibody labeling of sections cut from embedded explants incubated in normal culture media only. Grids were washed in TBS and water, stained with $2 \%$ aqueous uranyl acetate, and observed in a Philips CM 100 transmission electron microscope.

\section{RESULTS}

\section{Specificity of GTTR labeling}

Control explants were imaged using the same confocal settings for laser power, iris size, gain, and black levels as the contralateral saccular explant contemporaneously treated with GTTR. When saccular explants were incubated with $300 \mu \mathrm{g} / \mathrm{ml} \mathrm{GT/GTTR}$ (300:1 molar ratio) for $30 \mathrm{~min}$ prior to fixation and mounting, an intense band of fluorescence was pre- 


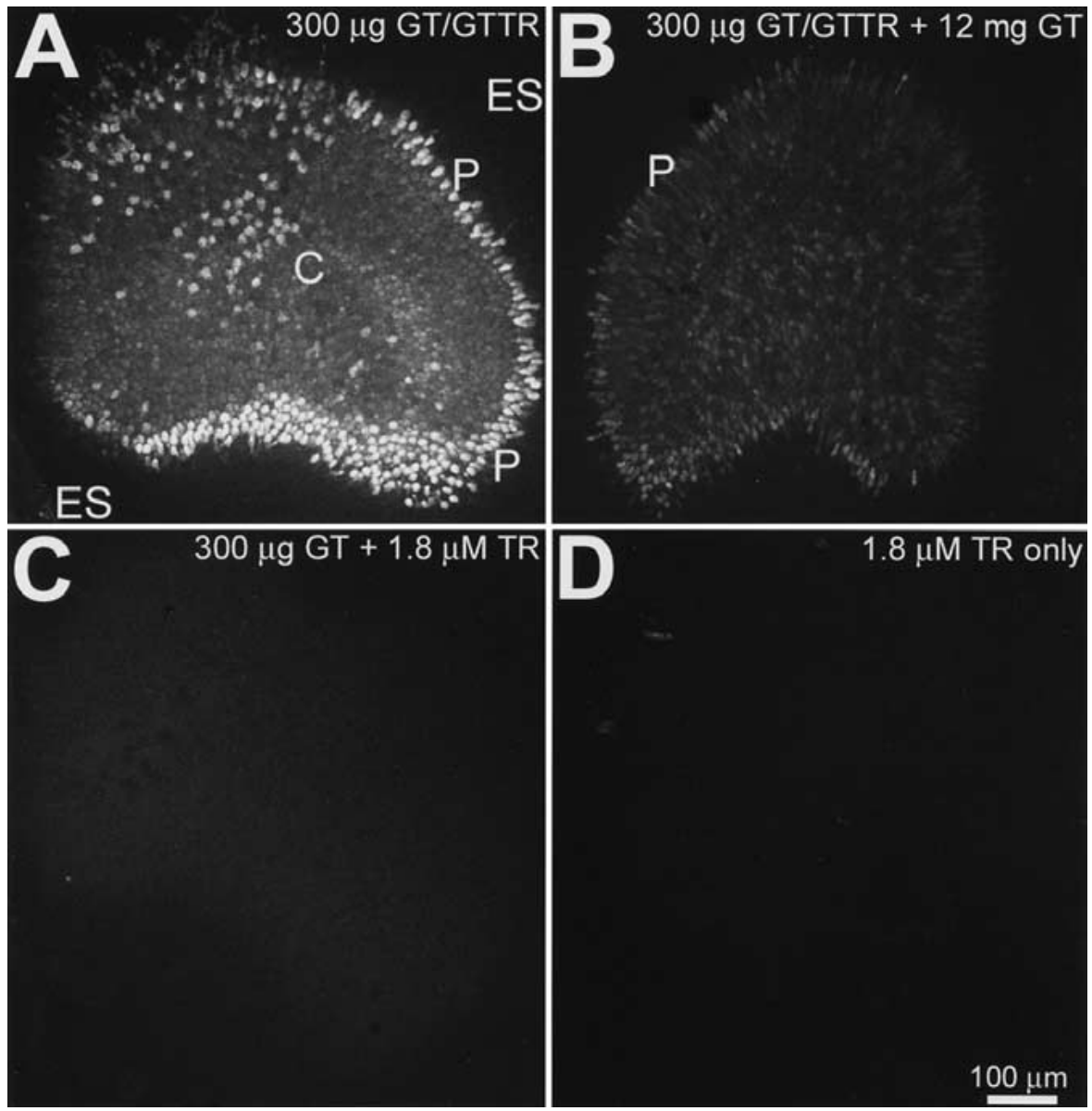

FIG. 1. GTTR fluorescence is reduced by excess free gentamicin and is not replicated by free Texas Red. A. Typical distribution of GTTR fluorescence in saccular explants following in vitro incubation with $300 \mu \mathrm{g} / \mathrm{ml} \mathrm{GT/GTTR} \mathrm{for}$ $30 \mathrm{~min}$. There are intensely labeled cells at the periphery $(\mathrm{P})$ of the sensory epithelium, less intensely labeled central cells (C) and negligible labeling in the extrasensory epithelium (ES). B. Explants incubated with $300 \mu \mathrm{g} / \mathrm{ml}$ GT/ GTTR plus $12 \mathrm{mg} / \mathrm{ml}$ free GT display reduced GTTR fluorescence in the sensory epithelium, particularly in the peripheral regions. C. Explants incubated with $300 \mu \mathrm{g} / \mathrm{ml}$ free GT plus $1.8 \mu \mathrm{M}$ unconjugated TR (equivalent to the concentration of TR in $300 \mu \mathrm{g} / \mathrm{ml}$ GT/GTTR) display negligible fluorescence within the sensory epithelium. D. Explants incubated with free TR alone also display negligible fluorescence. Scale bar in $\mu \mathrm{m}$.

sent around the edge of the sensory epithelium (Fig. 1A), with less intense fluorescence within the central region of the saccule (Fig. 1A). There is little fluorescence in the extrasensory epithelium (Fig. 1A).

Explants incubated with $300 \mu \mathrm{g} / \mathrm{ml}$ GTTR plus a $40-$ fold excess of unconjugated GT (i.e., $12 \mathrm{mg} / \mathrm{ml}$ ) displayed reduced fluorescence in the sensory epithelium, particularly in the peripheral regions (Fig. 1B). Explants incubated with $300 \mu \mathrm{g} / \mathrm{ml}$ free GT and 1.8 $\mu \mathrm{M}$ unconjugated (hydrolyzed) TR exhibited negligible fluorescence in the sensory epithelium (Fig. 1C), as did explants incubated with unconjugated TR alone (Fig. 1D). Thus, because GTTR fluorescence in saccular explants was reduced by excess free GT and was not replicated by free Texas Red, the fluorescence distribution pattern in explants treated with GT/GTTR was considered representative of GTTR localization.

\section{Distribution of GTTR in bullfrog saccular explants}

To identify the cell type(s) preferentially accumulating GTTR at the saccular periphery, explants were incubated with $300 \mu \mathrm{g} / \mathrm{ml} \mathrm{GT} /$ GTTR for $30 \mathrm{~min}$ prior to fixation, permeabilization, and labeling for filamentous actin with FITC-phalloidin. Intense FITC- phalloidin labeling revealed a kidney-shaped region of bright dots resembling the extent of the sensory epithelium and a reticulated network outlining cells throughout the epithelial sheet (Fig. 2A). The bright dots represent the hair cell bundles viewed from above. GTTR fluorescence occurred throughout the sensory epithelium and particularly at its periphery (Fig. 2B). Superimposition of the FITC-phalloidin and GTTR fluorescence signals revealed that the hair bundles of the sensory epithelium were further outlined by a perimeter of intense red fluorescent cells, outside of which there was little GTTR fluorescence (Fig. 2C, D). At higher magnification, the peripheral red fluorescent cells in the growth zone regions at the neural edge of the macula (Fig. 2B, D) and around the periphery of the sensory macula can be identified as hair cells, indicated by the FITC-labeled hair bundle, within a circular cell apex surrounded by supporting cells with green polygonal margins (Steyger et al. 1997). The red fluorescent signal (Fig. 2D; shown monochromatically in Fig. 2E) revealed minimal GTTR fluorescence in the supporting cells surrounding the fluorescent hair cells. Within the peripheral hair cells, GTTR fluorescence was punctate and also diffusely dispersed throughout the 

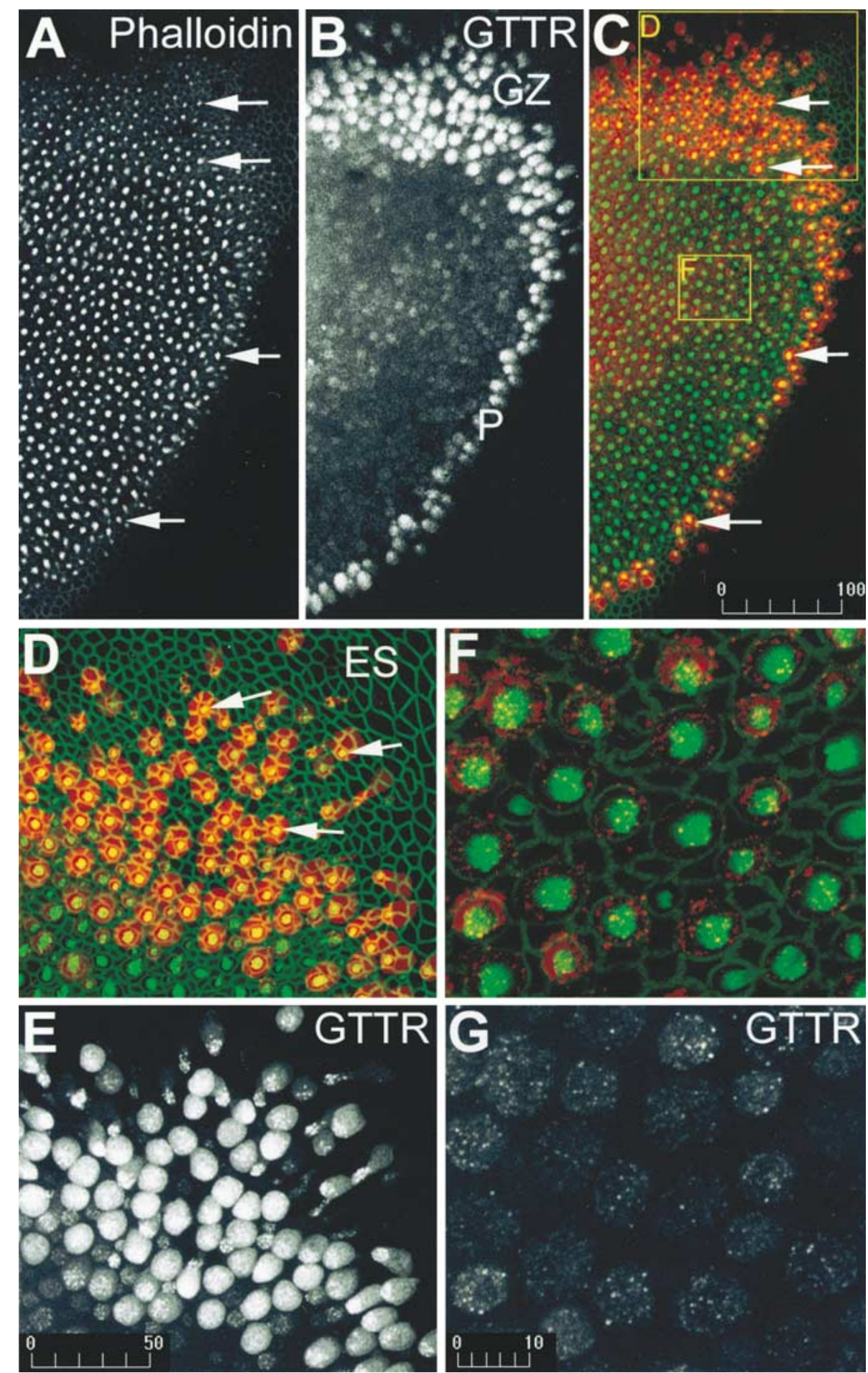

FIG. 2. GTTR is preferentially taken up by hair cells at the periphery of the saccular macula $30 \mathrm{~min}$ after addition of $300 \mu \mathrm{m} / \mathrm{ml}$ GT/GTTR. A. At low magnification, FITC-phalloidin labeling reveals a distinct pattern of bright dots (arrows) that represents the sensory hair bundles perpendicular to the surface of the sensory epithelium. B. GTTR fluorescence occurs throughout the sensory epithelium, and most prominently in the growth zone (GZ) and at the periphery $(\mathrm{P})$ of the sensory epithelium. C. A merged image of FITCphalloidin (green) and GTTR (red),

showing the hair bundles superimposed on GTTR-filled cell bodies (arrows). D. At higher magnification, the peripheral red fluorescent cells in the growth zone have intense green fluorescent hair bundles (arrows) at their cell apices. Note negligible GTTR fluorescence in the extrasensory epithelium (ES). E. The red signal only from the image in $\mathbf{D}$ reveals negligible labeling of nonhair cells and diffuse fluorescence in hair cells. GTTR fluorescence within peripheral hair cells is both punctate and diffuse. F. In the central region of the saccule, mature hair cells have large round apical surfaces, with an intensely fluorescent actiniferous hair bundle, and are surrounded by the green polygonal outlines of supporting cells. G. The red signal only from the image in F reveals punctate GTTR labeling with diffuse GTTR fluorescence within the hair cell soma only. Scale bars in $\mu \mathrm{m}$. elongated cell body (Fig. 2E). Hair cells with elongated cell bodies have been characterized as immature hair cells (Lewis 1985; Baird et al. 1996; Steyger et al. 1997). Within the central region of the sensory epithelium, large cells with circular apices exhibited less intense punctate GTTR fluorescence than peripheral hair cells, together with diffuse somatic fluorescence not present in adjacent cells (Fig. 2G). The large rotund cells displayed FITC-phalloidin labeling of a circular cell apex, from which a labeled hair bundle protrudes perpendicular to the surface of the sensory epithelium (Fig. 2F), characteristic of mature hair cells (Lewis 1985; Baird et al. 1996; Steyger et al. 1997). These mature hair cells were typically surrounded by polygonal supporting cells with negligible GTTR fluorescence (Fig. 2F, G). 

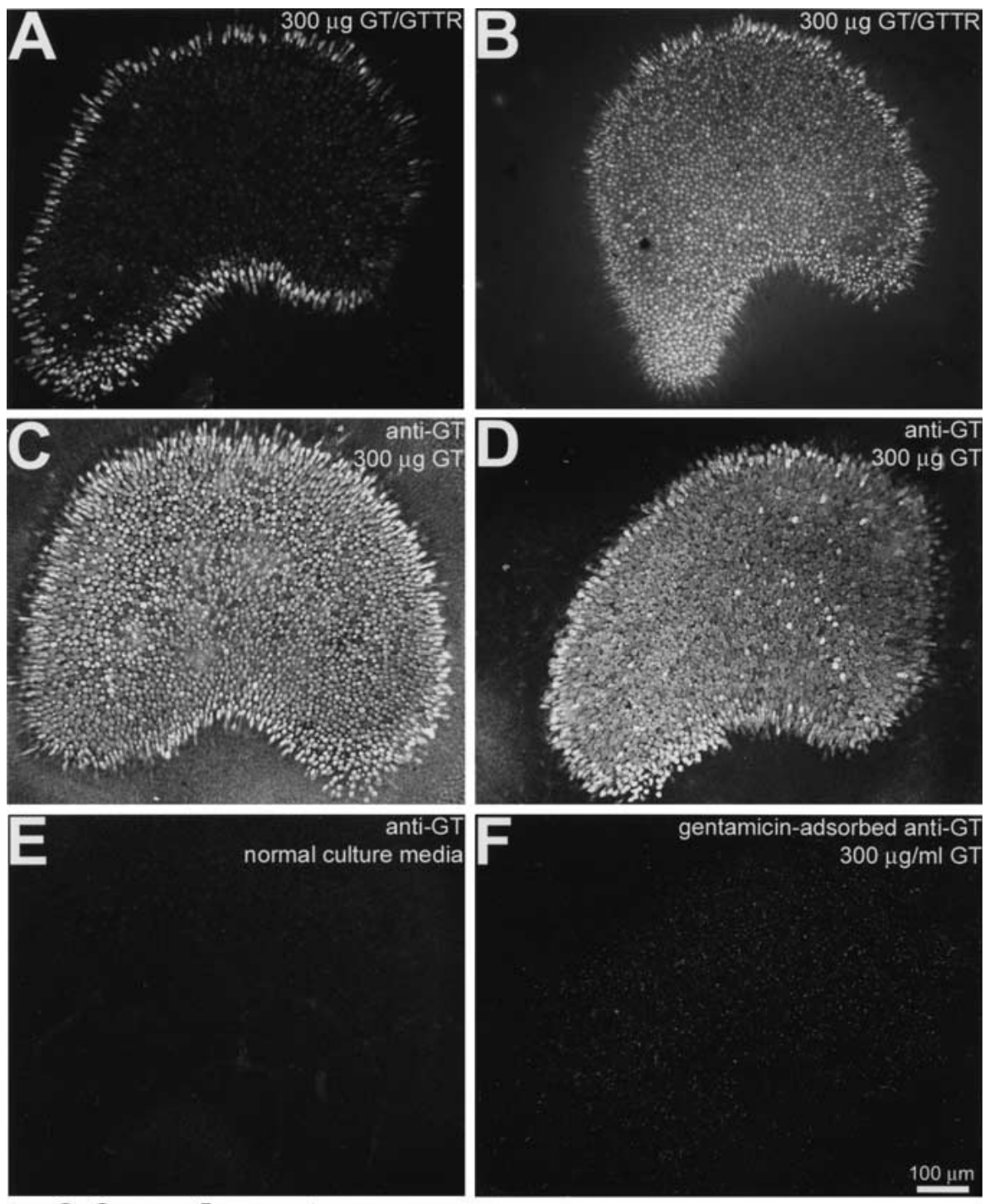

\section{0 minutes}

\section{2 hours}

FIG. 3. GTTR and immunolabeled GT share similar distribution patterns in saccular explants incubated for $30 \mathrm{~min}$ $(\mathbf{A}, \mathbf{C})$ or $2 \mathrm{~h}(\mathbf{B}, \mathbf{D})$. A. Explants incubated with $300 \mu \mathrm{m} / \mathrm{ml} \mathrm{GT/GTTR}$ for $30 \mathrm{~min}$ display GTTR fluorescence throughout thesensory epithelium and preferentially at the periphery. B. Explants incubated with $300 \mu \mathrm{m} / \mathrm{ml} \mathrm{GT/GTTR}$ for $2 \mathrm{~h}$ display less difference in the fluorescence between the peripheral and central zones. C. Explants incubated with gentamicin for 30 min or (D) $2 \mathrm{~h}$ prior to gentamicin immunofluorescent labeling, reveal labeling in hair cells throughout the saccule and somewhat preferentially at the periphery. E. Explants incubated in normal culture media for $30 \mathrm{~min}$ prior to fixation and then immunolabeled with gentamicin and secondary antibodies display negligible fluorescence. $\mathbf{F}$. Explants incubated with unconjugated GT for $2 \mathrm{~h}$ prior to fixation and immunolabeling with GT-adsorbed primary antibodies revealed negligible labeling. Scale bar in $\mu \mathrm{m}$.
Comparison of GTTR with immunolabeled gentamicin distributions

The distribution of GTTR fluorescence was compared with the distribution pattern of unconjugated gentamicin revealed by indirect immunofluorescence. In low-power images, explants incubated with $300 \mu \mathrm{g} / \mathrm{ml} \mathrm{GT} / \mathrm{GTTR}$ for $30 \mathrm{~min}$ displayed typical GTTR fluorescence throughout the sensory epithelium and preferentially at the periphery (Fig. 3A), as described earlier. After incubation with GT/GTTR for $2 \mathrm{~h}$, the difference in the intensity of fluorescence between the peripheral and central hair cell zones was substantially reduced (Fig. 3B).

Explants incubated with unconjugated GT for 30 min or $2 \mathrm{~h}$, detected using gentamicin immunocytochemistry, revealed immunolabeling throughout the sensory macula, with only a slight preferential in- crease in fluorescence at the periphery (Fig. 3C, D). Explants incubated in normal culture media without GT for $30 \mathrm{~min}$ had negligible fluorescence following incubation with GT antisera and secondary antibodies (Fig. 3E). Explants incubated with unconjugated GT for $30 \mathrm{~min}$, fixed, and immunolabeled with GTadsorbed primary antibodies revealed negligible labeling compared to positively labeled explants (Fig. $3 \mathrm{~F})$.

The distributions of GTTR and immunolabeled GT fluorescence in hair bundles were compared with phalloidin-Alexa-660 labeling in explants incubated with GTTR or unconjugated GT for $30 \mathrm{~min}$. Both GTTR and immunolabeled GT fluorescence were identified in the vicinity of phalloidin-labeled hair bundles of both mature and immature hair cells (Fig. 4). Colocalization analysis revealed numerous pixels within hair bundles that contained both red (GTTR 


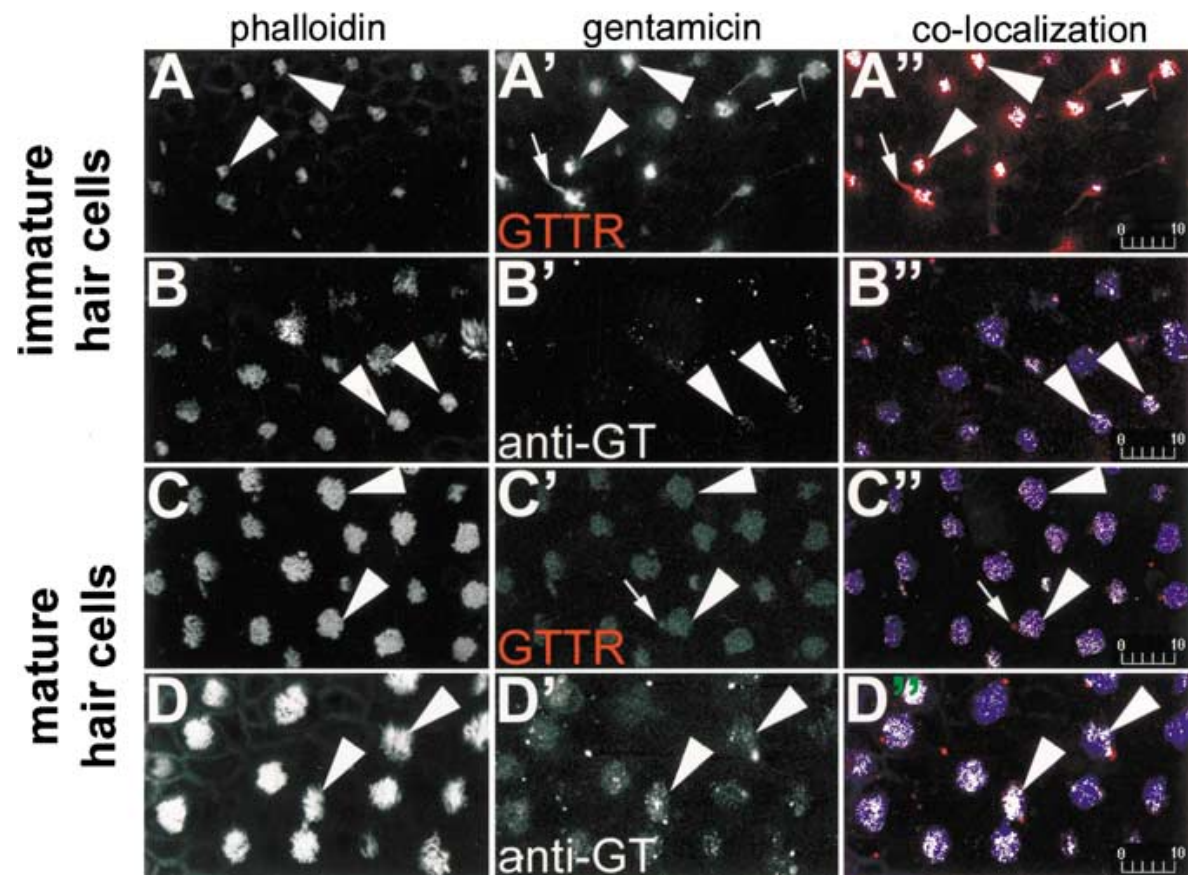

FIG. 4. GTTR and immunolabeled gentamicin are both localized in the hair bundle. In immature hair cells (A,B), phalloidin-Alexa-660labeled hair bundles $(-)$ appear above the sensory epithelium. GTTR $\left(\mathbf{A}^{\prime}\right)$ and immunolabeled gentamicin $\left(\mathbf{B}^{\prime}\right)$ fluorescence also occurs above the sensory epithelium in the region of the hair bundle $(\mathbf{D})$. Colocalization analysis of single optical planes of explants doublelabeled with phalloidin-Alexa-660 (blue) and GTTR $\left(\mathbf{A}^{\prime \prime}\right)$ or immunolabeled gentamicin $\left(\mathbf{B}^{\prime \prime}\right)$ reveal white pixels, indicating that immature hair bundles $(-)$ are colabeled with GTTR or gentamicin antibodies. The kinocilium of several hair cells labeled with GTTR can also be seen $(\rightarrow)$ in $\mathbf{A}^{\prime}$ and $\mathbf{A}^{\prime \prime}$. In the central saccule, mature hair cells labeled with phalloidin-Alexa-660-labeled hair bundles ( ) appear above the sensory epithelium $(\mathbf{C}, \mathbf{D})$. GTTR $\left(\mathbf{C}^{\prime}\right)$ or immunolabeled gentamicin $\left(\mathbf{D}^{\prime}\right)$ fluorescence also occurs above the sensory epithelium in the region of the hair bundle $(\boldsymbol{)})$, and verified by the white pixels in the colorized images using colocalization analysis $\left(\mathbf{C}^{\prime \prime}, \mathbf{D}^{\prime \prime}\right)$. The kinocilium of several mature hair bundles labeled with GTTR can also be seen $(\rightarrow)$ in $\mathbf{C}^{\prime}$ and $\mathbf{C}^{\prime \prime}$. All images are from explants incubated with $300 \mu \mathrm{g} / \mathrm{ml} \mathrm{GT/GTTR} \mathrm{or} \mathrm{unconju-}$ gated GT (and subsequently immunolabeled) for $30 \mathrm{~min}$. Scale bars in $\mu \mathrm{m}$.

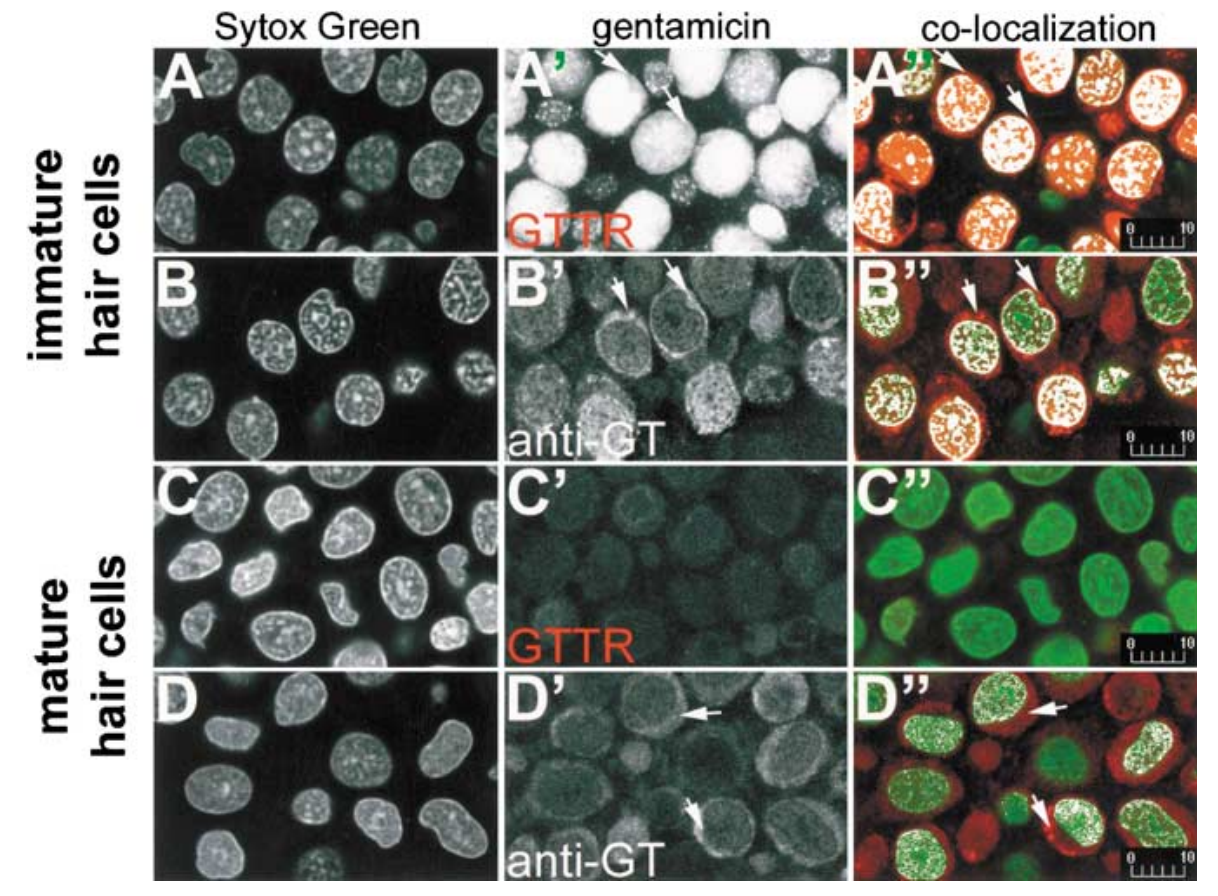

FIG. 5. GTTR and immunolabeled gentamicin are both localized in the nuclei of hair cells. In immature hair cells (A,B), Sytox Green-labeled nuclei appear at the periphery of the sensory epithelium. GTTR $\left(\mathbf{A}^{\prime}\right)$ and immunolabeled gentamicin $\left(\mathbf{B}^{\prime}\right)$ occur in the same optical plane as Sytox Greenlabeled nuclei. Colocalization analysis of single optical planes of nuclei doublelabeled with Sytox Green and GTTR ( $\left.\mathbf{A}^{\prime \prime}\right)$ or immunolabeled gentamicin $\left(\mathbf{B}^{\prime \prime}\right)$ reveal white pixels, indicating nuclei or regions that are colabeled with GTTR or gentamicin antibodies. Only immunolabeled gentamicin $\left(\mathbf{D}^{\prime \prime}\right)$, but not $\operatorname{GTTR}\left(\mathbf{C}^{\prime \prime}\right)$, can be readily seen in the nuclei of mature hair cells. GTTR $\left(\mathbf{A}^{\prime}, \mathbf{A}^{\prime \prime}\right)$ and immunolabeled gentamicin

$\left(\mathbf{B}^{\prime}, \mathbf{B}^{\prime \prime}, \mathbf{D}^{\prime}, \mathbf{D}^{\prime \prime}\right)$ is also present in the perinuclear cytoplasm $(\rightarrow)$. All images are from explants incubated with $300 \mu \mathrm{g} /$ $\mathrm{ml} \mathrm{GT/GTTR} \mathrm{or} \mathrm{unconjugated} \mathrm{GT} \mathrm{(and}$ subsequently immunolabeled) for 30 min. Scale bars in $\mu \mathrm{m}$. 
or immunolabeled gentamicin) and blue (phalloidinAlexa-660) intensities above a user-defined threshold, confirming that phalloidin-labeled stereocilia were labeled with either GTTR or GT antibodies. The kinocilium of several immature and mature hair cells also exhibited GTTR fluorescence (Fig. 4). No cross talk or bleed-through of Alexa-660-phalloidin fluorescence could be determined in the Texas Red channel (or vice versa) at the same laser power and acquisition settings used to collect stereociliary images (data not shown).

The distributions of GTTR and immunolabeled GT fluorescence in hair cell nuclei were also compared in explants incubated with GTTR or unconjugated GT for $30 \mathrm{~min}$ and subsequently labeled with Sytox Green that is specific for nucleic acids (Fig. 5). At the saccular periphery, GTTR and immunolabeled GT were both present within immature hair cell nuclei (Fig. 5A', B'). Co-localization analysis revealed many pixels in immature hair cell nuclei that contained GTTR or immunolabeled GT fluorescence at intensities above a user-defined threshold, confirming that these nuclei were labeled with GTTR or GT antibodies (Fig. 5A', B'). In mature hair cells, only immunolabeled GT could be readily identified in the nuclei (Fig. 5D"). No cross talk of Sytox Green fluorescence could be determined in the Texas Red channel at the same laser power and acquisition settings used to collect these images (data not shown).

\section{Subcellular compartmentalization of GTTR}

Live saccular explants preloaded with Lysotracker Green, Mitotracker Green, NBD-ceramide, and ERtracker were treated with GTTR for $2 \mathrm{~h}$, prior to washout and imaging. Colocalization analysis (Fig. $\left.6 \mathrm{~A}^{\prime}-\mathrm{D}^{\prime}\right)$ revealed that the pixel clusters of punctate (red) GTTR fluorescence were colocalized with clusters of green pixels generated by fluorescence emission of Lysotracker Green, Mitotracker Green, NCBceramide, and ERtracker. The resolution of the confocal microscopy system $(>230 \mathrm{~nm}, \times 60$ objective, N.A. 1.4) demonstrates that GTTR fluorescence is in the vicinity of these organelles.

\section{Ultrastructural localization of gentamicin}

On LR Gold sections, GT immunogold labeling was observed in the vicinity of the hair bundle and at the endolymphatic membrane of hair cells. Labeling was also observed within endosomes and other vesicular structures in the infracuticular regions of all hair cell types, adjacent to and within mitochondria, and within the nucleus (Figs. 7 and 8). Often, gold particles could not be assigned to a particular structure
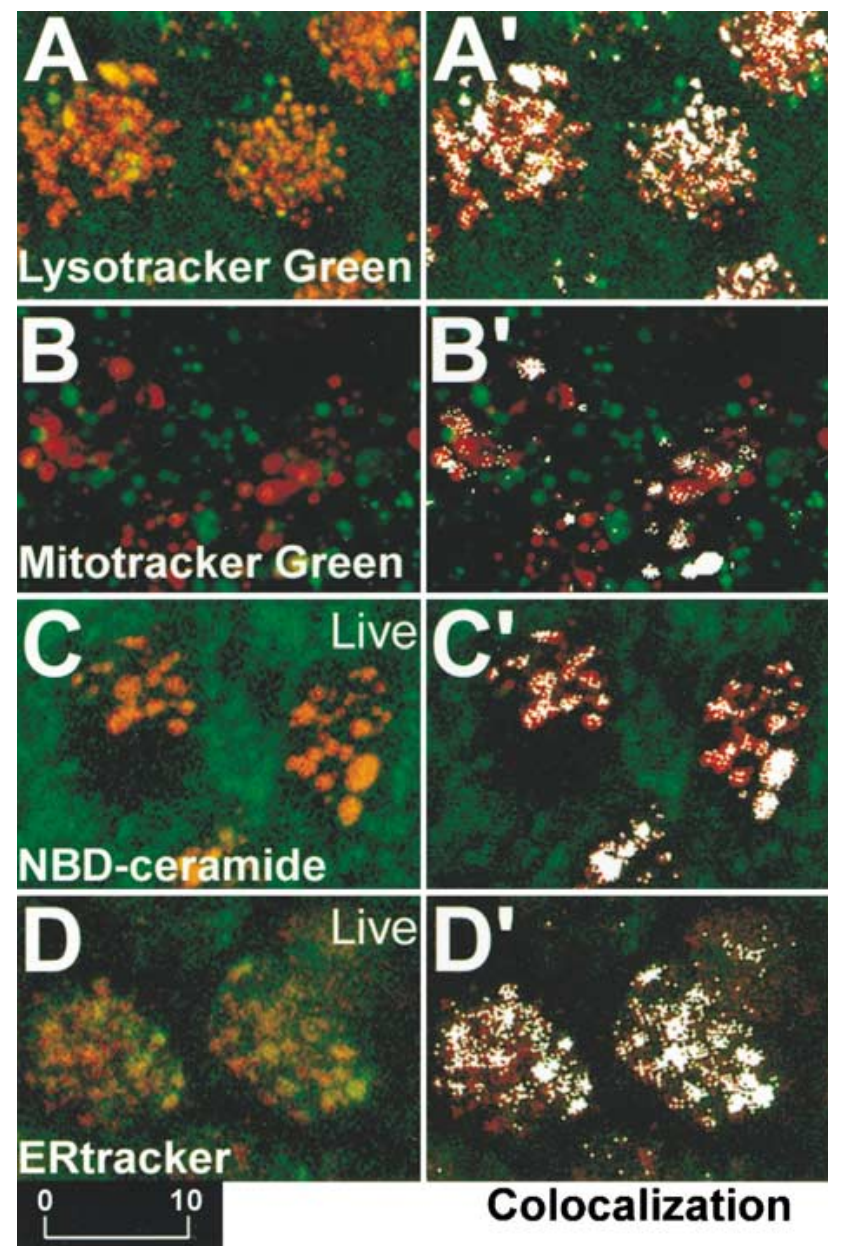

Colocalization

FIG. 6. A-D. Explants preloaded with Lysotracker Green, Mitotracker Green, NBD-ceramide, and ERtracker that fluorescently label lysosomes, mitochondria, Golgi bodies, and ER, respectively, and subsequently incubated with GTTR for $2 \mathrm{~h}$. $\left(\mathbf{A}^{\prime}-\mathbf{D}^{\prime}\right)$. Colocalization analysis reveals as white pixels those areas where the red and green fluorescence intensities are above a user-defined threshold, indicating that GTTR is colocalized in the region of fluorescently labeled lysosomes $\left(\mathbf{A}^{\prime}\right)$, mitochondria $\left(\mathbf{B}^{\prime}\right)$, Golgi bodies $\left(\mathbf{C}^{\prime}\right)$ and ER $\left(\mathbf{D}^{\prime}\right)$. Scale bar in $\mu \mathrm{m}$.

and yet were present in significant numbers in the hair cell cytoplasm (Fig. 7A, and inset; 7C, D, E). No qualitative differences in the distribution of gold labeling could be determined at this ultrastructural level between mature and immature hair cells. The cytoplasmic immunogold labeling seen within hair cells could not be observed in adjacent supporting cells (Fig. 7A) or in hair cells from explants not incubated with GT (Fig. 7B). Thus, this cytoplasmic labeling may be the ultrastructural equivalent of the diffuse fluorescent labeling seen in hair cells (Fig. 2). Supporting cells displayed comparatively weak gold labeling in the nucleus compared with hair cell nuclei (Fig. 8C). Control sections of explants incubated with GT and immunoprocessed without primary antibodies, or with GT-adsorbed GT antibodies, displayed 

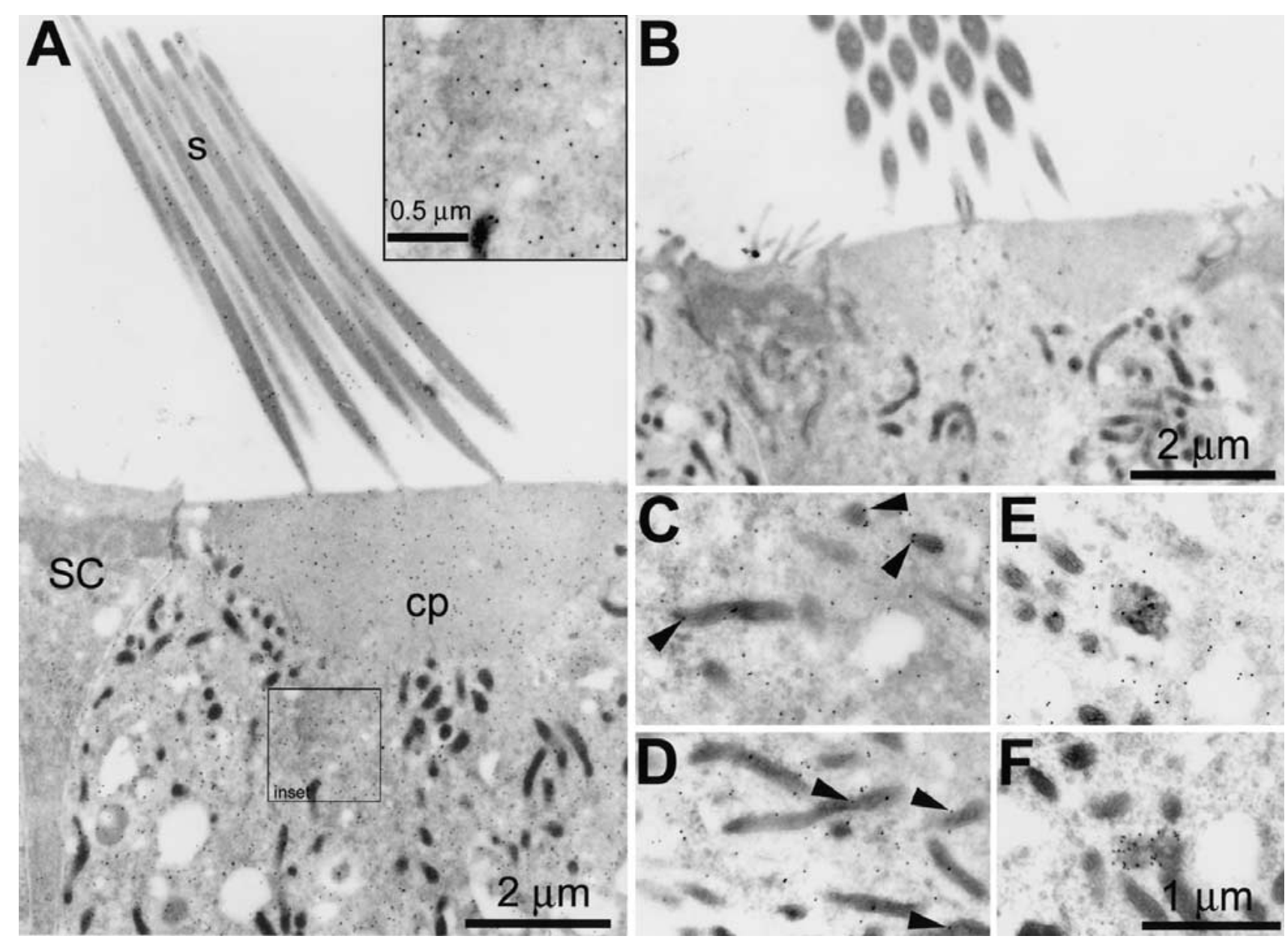

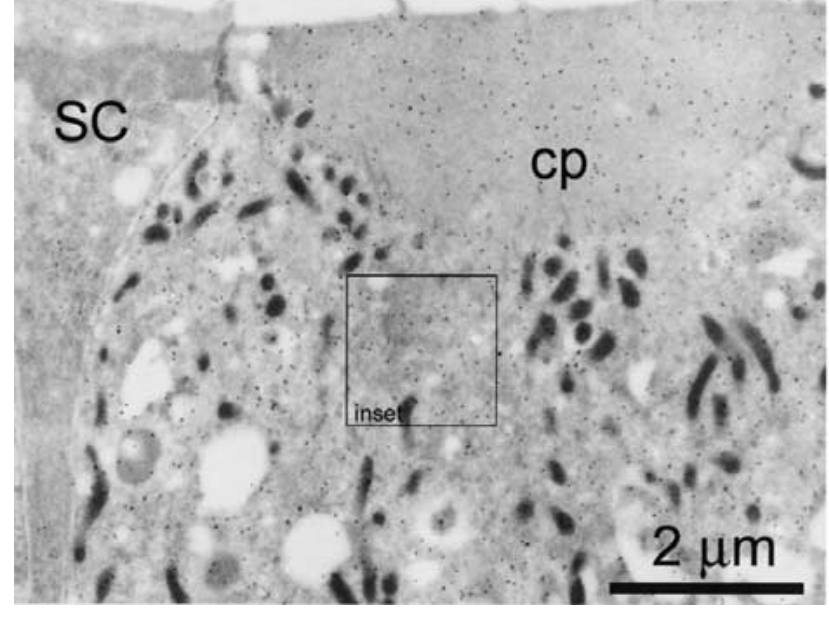

FIG. 7. Gentamicin immunoelectron microscopy of mature hair cells on LR Gold sections. A. Immunogold labeling for gentamicin in a saccular hair cell is typically located in the vicinity of stereocilia (s), in the cuticular plate (cp), throughout the hair cell cytoplasm (see also inset), and often is associated with mitochondria (as in C,D). Note the comparative lack of labeling in the adjacent supporting cell

negligible gold labeling (not shown). Sections of control explants (without GT treatment) incubated in the presence of GT antisera and secondary antibodies also displayed negligible nonspecific labeling (Fig. 7B), except for very weak nonspecific labeling in the hair cell nucleus (Fig. 8B, compared with gentamicin-treated explants; Fig. 8A).

\section{DISCUSSION}

Gentamicin ototoxicity remains a serious clinical and socioeconomic problem despite gentamicin's proven efficacy in treating Gram-negative bacterial infections like meningitis and its routine administration to premature babies to prevent infection. Although gentamicin has been known to induce ototoxicity since the 1960s (Hawkins et al. 1969; Wersall et al.
(SC). B. Antigentamicin immunogold labeling of sections cut from an explant incubated with normal culture media reveals negligible nonspecific labeling. C,D. Immunogold labeling for gentamicin is often associated with mitochondria $(-)$ and $(\mathbf{E}, \mathbf{F})$ as clusters associated with electron dense inclusions within the cytoplasm. Scale bars in $\mu \mathrm{m}$.

1969), the mechanism by which it ultimately initiates hair cell death still remains unclear. Long-standing hypotheses suggest that endocytotic uptake of aminoglycosides and processing through Golgi bodies or lysosomes lead to the death of inner ear hair cells and kidney proximal tubule cells (Giuliano et al. 1984; Gratacap et al. 1985; Ding et al. 1995; Hashino and Shero 1995; Hashino et al. 1997, 1998, 2000; Sandoval et al. 1998, 2000). However, more recent evidence suggests that aminoglycosides may access the hair cell cytoplasm via the stereociliary mechanosensory transduction channels (Gale et al. 2001; Marcotti and Kros 2002). Aminoglycosides increase intracellular levels of both calcium and reactive oxygen species in hair cells and kidney cells (Staecker et al. 1996; Hirose et al. 1997, 1999; McLarnon et al. 2002; Ward et al. 2002) and induce changes in the cytoskeletal organization and cytochemical composition of hair cells (Hackney et al. 1990; Steyger 1991; Imamura 


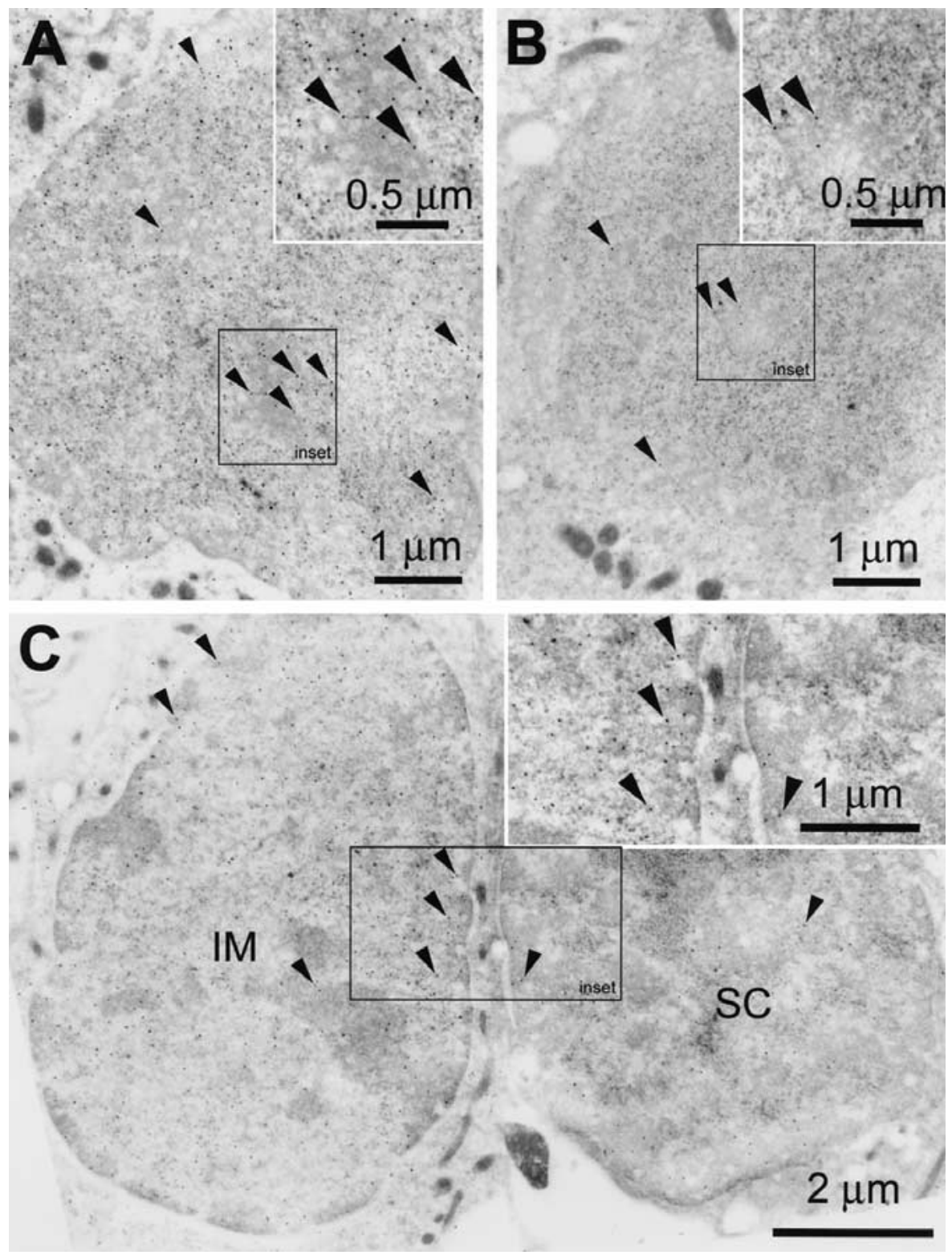

FIG. 8. Gentamicin immunoelectron microscopy. A. Immunogold labeling ( for gentamicin is also strongly associated with the nucleus of mature hair cells; inset (=outlined area in main panel) shows strong labeling within the center of the nucleus. B. Antigentamicin immunogold labeling sections cut from an explant not incubated withgentamicin reveals some nonspecific labeling within the nucleus. Inset shows little nonspecific gold labeling within the center of the nucleus. C. Immunogold labeling for gentamicin is also associated with the nucleus of immature hair cells (IM), with a comparative lack of labeling in adjacent supporting cell nucleus (SC). Inset shows strong gold labeling within the center of the immature hair cell nucleus compared with the supporting cell nucleus. Scale bars in $\mu \mathrm{m}$.

and Adams 2003a), all of which are indicators of cellular progression along the cell death pathway. A better understanding of aminoglycoside interaction with all (intra-)cellular components is required to comprehend the mechanisms of toxicity in aminoglycoside-sensitive cells.

\section{Distribution of GTTR fluorescence}

Negligible fluorescence in confocal images of explants incubated with unconjugated Texas Red (in the presence or absence of unconjugated gentamicin) demonstrates the specificity of the fluorescence as originating from the gentamicin-Texas Red conjugate (GTTR), rather than from free unconjugated Texas Red molecules. These in vitro studies used constant gentamicin levels as in previous in vitro studies and direct intraotic gentamicin injections of bullfrogs (Baird et al. 1993, 1996; Steyger et al. 1997). However, these in vitro and intraotic methods invoke higher aminoglycoside concentrations in inner ear fluids than those achieved following systemic injections in vivo, where aminoglycoside accumulation in inner ear fluids vary as a function of access, time, and serum clearance (Tran Ba Huy et al. 1981). Whether this constant (higher) concentration of gentamicin in culture media affects the route(s) by which GTTR enters hair cells in vitro remains to be determined. If $300 \mu \mathrm{g} / \mathrm{ml}$ gentamicin $(<0.5 \mathrm{mM})$ in culture media were to induce membrane rupture and artifactual entry of both gentamicin and GTTR, then much higher concentrations of gentamicin should increase 
that effect. However, decreased fluorescence in explants incubated with GT/GTTR with an additional $12 \mathrm{mg} / \mathrm{ml}$ gentamicin (Fig. 1B) contraindicates this possibility.

The distribution of GTTR fluorescence in saccular explants is remarkably similar to that observed for immunolabeled gentamicin, at both light and EM levels. The fluorescence of GTTR was also only slightly more intense in peripheral hair cells than in mature hair cells after exposure to gentamicin for $2 \mathrm{~h}$ (as was the fluorescence of immunolabeled gentamicin after $30 \mathrm{~min}$ or $2 \mathrm{~h}$ ). The qualitatively more intense punctate GTTR fluorescence in peripheral hair cells compared with mature hair cells at early time points may be due to increased endocytotic activity in peripheral hair cells, as observed in other explant protocols (Stanislawski et al. 1997). Indeed, the preferential accumulation of GTTR by peripheral hair cells is not replicated in in vivo studies following systemic injection. In these studies using GTTR, there was always a 300 -fold excess of unlabeled GT. This may have resulted in competition between gentamicin and GTTR for binding sites, transporters, or ion channels which would not occur in GT-only treated explants. In fact, in these immunocytochemical experiments, all the gentamicin is available for immunodetection.

Aminoglycosides are used routinely to block the mechanoelectrical transduction channel (Denk et al. 1992). Thus, the presence of GTTR and immunolabeled gentamicin at the location of the hair bundle of mature and immature hair cells is unsurprising, corroborating previous reports (Tachibana et al. 1985, 1986; Richardson et al. 1989). These ultrastructural studies are not able to distinguish fluorescent or immunogold labeling binding to glycocalyceal or membraneous structures of the hair bundle (Au et al. 1987; Marche et al. 1987; Richardson et al. 1989) from binding within the stereocilia.

Mature hair cell nuclei were also strongly immunolabeled for gentamicin, but only weakly labeled by GTTR. This may be a function of molecular size limiting the passage of GTTR (compared with unconjugated gentamicin) through the cytoplasm and through nuclear pores in mature hair cells; however, immature hair cell nuclei are strongly labeled by GTTR. Mature hair cells may have greater cytoplasmic affinity for GTTR (because of their larger volume), or ability to sequester GTTR in vesicles, compared with immature hair cells, thereby reducing passage of GTTR to the nucleus. If so, this may limit the utility of the GTTR conjugate. Alternatively, the stronger presence of immunolabeled gentamicin in mature hair cell nuclei, compared with GTTR at early time points, may be due to competition between GTTR and unlabeled gentamicin for entry into the nuclei. Competition experiments between GTTR and unlabeled gentamicin during cellular accumulation is currently under investigation in this laboratory.

In the hair cell soma, GTTR is colocalized with fluorescence emissions of Lysotracker Green-, Mitotracker Green-, NBD-ceramide-, or ERtracker-labeled organelles in hair cells within $2 \mathrm{~h}$, suggesting that GTTR is accumulated by lysosomes, mitochondria, Golgi bodies, and ER after uptake, as in kidney cells (Sandoval et al. 1998, 2000). Although the resolution $(>230 \mathrm{~nm})$ of the confocal microscopy technique cannot confirm that GTTR is within the organelle membranes of these subcompartments, GTTR is located at least in the vicinity of these subcellular membrane-bound structures.

Gentamicin immunogold labeling was localized on the stereocilia and within the cuticular plate. Labeling was also associated with membrane-bound vesicles in the infracuticular cytoplasm and mitochondria and was distinctly above background levels within the nucleus. This confirms the patterns of GTTR and immunolabeled gentamicin fluorescence obtained using confocal microscopy. The overall GTTR and immunolabeled gentamicin distributions reported here also correspond closely with the previous localization of aminoglycosides in lysosomes, nuclei, and mitochondria of hair cells in previous studies (de Groot et al. 1990; Ding et al. 1995, 1997; Hashino et al. 1997).

The distribution of gentamicin within hair cells is not solely confined to subcellular compartments like mitochondria and lysosomes. A significant fraction of GTTR and gentamicin immunolabeling was diffusely distributed throughout the cytoplasm (Figs. 2, $\left.5 \mathrm{~A}^{\prime}, \mathrm{A}^{\prime \prime}\right)$ and unassociated with particular structures in postembedding immunoelectron microscopy (Fig. 7), confirming previous reports of cytoplasmic labeling in kidney proximal tubules, retinal neurons, and guinea pig organ of Corti (Wedeen et al. 1983; Tabatabay et al. 1990; Beauchamp et al. 1991). Figure 6 , illustrating the colocalization of GTTR with fluorescently labeled organelles, shows an apparent lack of cytoplasmic GTTR labeling. This may be due to the intense fluorescence of the organelle-associated GTTR overwhelming the cytoplasmic labeling. In addition, explants used in Figure 6 were not solvent-permeabilized, as were explants used in Figures $2-5$. We have recently found that solvent treatment unquenches masked GTTR fluorescence through delipidation (S. Myrdal, personal communication). Thus, the overall degree of correspondence between GTTR and immunolabeled gentamicin in these studies suggests that GTTR reaches the same intracellular locations as unconjugated gentamicin. In addition, these distributions largely agree with the distribution of aminoglyco- 
sides administered both systemically and in vitro in previous studies.

\section{Consequences of gentamicin accumulation}

The accumulation of gentamicin by a variety of subcellular organelles suggests a variety of interactions between aminoglycosides and eukaryote cells, ranging from interactions with ion channels/receptors, endocytotic uptake, to modulating intracellular chemical activities. Gentamicin promotes calcium influx via the calcium-sensing receptor (McLarnon et al. 2002; Ward et al. 2002). Aminoglycosides also block stereociliary mechanosensitive transduction channels and have recently been reported to enter hair cells via these same channels (Hudspeth 1982; Kroese and van den Bercken 1982; Hudspeth and Kroese 1983; Gale et al. 2001; Marcotti and Kros 2002). Entry of aminoglycosides into the cytoplasmic domain could facilitate accumulation by mitochondria and nuclei via diffusion or cytoplasmic trafficking rather than by endosomal transport.

Aminoglycosides (and FM1-43) are thought to enter the cytoplasmic domain of hair cells through cation channels (Gale et al. 2001; Marcotti and Kros 2002; Meyers et al. 2003). Could GTTR do the same? Although the polycationic GTTR has a molecular weight 2.5-3 times greater than native gentamicin (see Methods), other large organic molecules, e.g., tetrahexylammonium, YO-PRO, can pass through cation channels (Khakh et al. 1999; Virginio et al. 1999; Huang et al. 2000). Several characteristics other than molecular weight, e.g., physical dimensions, charge, hydrophobicity, also impact the ability of any specific molecule to permeate through any particular ion channel. We are currently testing the hypothesis that the amphiphilic GTTR molecule can permeate through cation channels.

Receptor-mediated endocytosis is a major mechanism of gentamicin uptake in kidney cells, where megalin and cubulin potentially play significant roles (Moestrup et al. 1995; Christensen and Bira 2001). Endosomal trafficking of GTTR leads to the endoplasmic reticulum (ER), Golgi bodies, and lysosomes (Sandoval et al. 1998, 2000; Sundin et al. 2001). Lysosomal retention of aminoglycosides by surviving hair cells following treatment has been implicated in the continuing degeneration of hair cells following cessation of treatment (Aran et al. 1993; Dulon et al. 1993; Hashino et al. 2000), but whether this is the primary site of aminoglycoside toxicity remains unclear. If lysosomal lysis were the major mechanism of aminoglycoside toxicity, the release of lysosomal hydrolases should accelerate the rate of necrosis. However, chronic low-level exposure to aminoglyco- sides increases the rate of apoptosis of kidney proximal tubule cells, but not necrosis (El Mouedden et al. 2000a; Ward et al. 2002).

Gentamicin toxicity also induces intracellular oxidative stress and the release of mitochondrial enzymes, including cytochrome $\mathrm{C}$, that are powerful promoters of apoptosis (Deshmukh and Johnson 1998; Hirose et al. 1999; Sha and Schacht 1999a,b; Walker et al. 1999; Cheng et al. 2002). Thus, the association of gentamicin with mitochondria is not surprising. The mechanism(s) by which gentamicin induces functional changes in mitochondria still remains unclear. Nonetheless, loss of mitochondrial function will have severe ramifications in the highly metabolically active hair cells, including oxidative stress, increase in free oxygen radicals, and loss of ATP production, all of which contribute to induction of apoptosis.

Nuclear accumulation of gentamicin suggests that gentamicin could directly interact with nuclear material rapidly after uptake. Several previous studies have shown nuclear uptake of aminoglycosides in both the ear and kidney (Nassberger et al. 1990; Beauchamp et al. 1991; Ding et al. 1995, 1997). However, other studies have reported neither the presence nor absence of gentamicin in the nucleus (Hashino et al. 1997; Sundin et al. 1997; Girton et al. 2002). Nonetheless, a subset of cystic fibrosis patients can be partially rehabilitated through gentamicin therapy, which causes bypassing of the premature stop codon in the cystic fibrosis (CF) mutation, allowing functional transcription of the CF transmembrane protein (Howard et al. 1996; Bedwell et al. 1997; Wilschanski et al. 2000; Clancy et al. 2001; Du et al. 2002; Zsembery et al. 2002). This suggests that gentamicin can enter the nucleus.

Although accumulation of gentamicin causes numerous cytochemical (Imamura and Adams 2003a), cytoskeletal (Hackney et al. 1990; Steyger 1991), and physiological changes (Staecker et al. 1996; Hirose et al. 1997, 1999; McLarnon et al. 2002; Ward et al. 2002), the functional impact of aminoglycoside accumulation in hair cells still remains poorly understood. The data in this article show the validity of using fluorophore-conjugated gentamicin (GTTR) to characterize the intracellular distribution of gentamicin in fixed, whole-mounted tissues. It permits the acquisition of high-resolution, 3-dimensional datasets not possible with sectioned material. This fluorescent conjugate also avoids the regulatory, safety, and environmental issues inherent when using radio-labeled compounds in autoradiography. Current studies are assessing the potential for GTTR in pharmacokinetic studies to identify the mechanisms involved in gentamicin accumulation and toxicity. 


\section{ACKNOWLEDGEMENTS}

We thank Sigrid Myrdal, Ph.D., and Dennis Trune, Ph.D., for scientific discussions related to this article. These studies were supported by NIDCD DC 03028, DC04555, Oregon Lions Sight \& Hearing Foundation (PSS), and China Scholarship Council (No. 20361037; CFD). The technical assistance of Aurelie Snyder for deriving the observed resolution of the confocal microscopy system is gratefully appreciated. The skilled technical support of Cindy Moore, and the low-temperature embedding equipment in Dr. Charles Meshul's laboratory, Portland Veterans Administration Medical Center, Oregon, were instrumental in the immunoEM studies.

\section{REFERENCES}

Aran JM, Dulon D, Hiel H, Erre JP, Aurousseau C. [Ototoxicity of aminosides: recent results on uptake and clearance of gentamycin by sensory cells of the cochlea]. Rev. Laryngol. Otol. Rhinol. 114:125-128, 1993.

Au S, Weiner ND, Schacht J. Aminoglycoside antibiotics preferentially increase permeability in phosphoinositide-containing membranes: a study with carboxyfluorescein in liposomes. Biochim. Biophys. Acta 902:80-86, 1987.

BaIrd RA, Torres MA, Schuff NR. Hair cell regeneration in the bullfrog vestibular otolith organs following aminoglycoside toxicity. Hear. Res. 65:164-174, 1993.

BAIRd RA, STEYger PS, Schuff NR. Mitotic and nonmitotic hair cell regeneration in the bullfrog vestibular otolith organs. Ann N Y Acad Sci 781:59-70, 1996.

BARZA M, LAUERMANN M. Why monitor serum levels of gentamicin? Clin. Pharmacokinet. 3:202-215, 1978.

Beauchamp D, Gourde P, Bergeron MG. Subcellular distribution of gentamicin in proximal tubular cells, determined by immunogold labeling. Antimicrob. Agents Chemother. 35:2173-2179, 1991.

Bedwell DM, Kaenjak A, Benos DJ, Bebok Z, Bubien JK, Hong J, Tousson A, Clancy JP, Sorscher EJ. Suppression of a CFTR premature stop mutation in a bronchial epithelial cell line. Nat. Med. 3:1280-1284, 1997.

Cheng AG, Cunningham LL, Rubel EW. Translocation of cytochrome $\mathrm{c}$ in hair cells of gentamicin-treated avian basilar papilla. Assoc. Res. Otolaryngol. Abstr. 25:134, 2002.

Christensen EI, BIRn H. Megalin and cubilin: synergistic endocytic receptors in renal proximal tubule. Am. J. Physiol. Renal. Physiol. 280:F562-F573, 2001.

Clancy JP, Bebok Z, Ruiz F, King C, Jones J, Walker L, Greer H, Hong J, Wing L, Macaluso M, Lyrene R, Sorscher EJ, Bedwell DM. Evidence that systemic gentamicin suppresses premature stop mutations in patients with cystic fibrosis. Am. J. Respir. Crit. Care Med. 163:1683-1692, 2001.

de Groot JC, Meeuwsen F, Ruizendaal WE, Veldman JE. Ultrastructural localization of gentamicin in the cochlea. Hear. Res. 50:35-42, 1990.

Denk W, Keolian RM, Webi WW. Mechanical response of frog saccular hair bundles to the aminoglycoside block of mechanoelectrical transduction. J. Neurophysiol. 68:927-932, 1992.

Deshmukn M, Johnson Jr JE. Evidence of a novel event during neuronal death: development of competence-to-die in response to cytoplasmic cytochrome c. Neuron 21:695-705, 1998.

Ding D, Jin X, ZhaO J. [Accumulation sites of kanamycin in cochlear basal membrane cells]. Zhonghua Er Bi Yan Hou Ke Za Zhi 30:323-325, 1995.
Ding D, Jin X, ZhaO J. [Accumulation sites of kanamycin in the organ of Corti by microautoradiography]. Zhonghua Er Bi Yan Hou Ke Za Zhi 32:348-349, 1997.

Du M, Jones JR, Lanier J, Keeling KM, Lindsey JR, Tousson A, Bebok Z, Whitsett JA, Dey CR, Colledge WH, Evans MJ, Sorscher EJ, Bedwell DM. Aminoglycoside suppression of a premature stop mutation in a Cftr-/- mouse carrying a human CFTR-G542X transgene. J. Mol. Med. 80:595-604, 2002.

Dulon D, Hiel H, Aurousseau C, Erre JP, Aran JM. Pharmacokinetics of gentamicin in the sensory hair cells of the organ of Corti: rapid uptake and long term persistence. C. R. Acad. Sci. III 316:682-687, 1993.

El Mouedden M, Laurent G, Mingeot-Leclero MP, Taper hS, Cumps J, Tulkens PM. Apoptosis in renal proximal tubules of rats treated with low doses of aminoglycosides. Antimicrob. Agents Chemother. 44:665-675, 2002a.

El Mouedden M, Laurent G, Mingeot-Leclerce MP, Tulkens PM. Gentamicin-induced apoptosis in renal cell lines and embryonic rat fibroblasts. Toxicol. Sci. 56:229-239, 2000b.

Gale Je, Marcotti W, Kennedy HJ, Kros CJ, Richardson GP. FM1-43 dye behaves as a permeant blocker of the haircell mechanotransducer channel. J. Neurosci. 21:7013-7025, 2001.

Girton RA, Sundin DP, Rosenburg ME. Clusterin protects renal tubular epithelial cells from gentamicin-mediated cytotoxicity. Am. J. Physiol. Renal Physiol. 282:F703-F709, 2002.

Giuliano RA, Paulus GJ, Verpooten GA, Pattyn VM, Pollet De, Nouwen EJ, Laurent G, Carlier MB, Maldague P, Tulkens PM, et al. Recovery of cortical phospholipidosis and necrosis after acute gentamicin loading in rats. Kidney Int. 26:838-847, 1984.

Gratacap B, Charachon R, Stoebner P. Results of an ultrastructural study comparing stria vascularis with organ of Corti in guinea pigs treated with kanamycin. Acta Otolaryngol. (Stockh.) 99:339-342, 1985.

HACKNEY CM, Furness DN, STEYgER PS1990Structural abnormalities in inner hair cells following kanamycin-induced outer hair cell loss. In: Dallos P, Geisler CD, Matthews JW, Ruggero M, Steele CR (Eds.) Mechanics and Biophysics of Hearing. SpringerVerlag, Berlin, New York, pp 10-17, 1989.

Hashino E, Shero M. Endocytosis of aminoglycoside antibiotics in sensory hair cells. Brain Res. 704:135-140, 1995.

Hashino E, Shero M, SAlvi RJ. Lysosomal targeting and accumulation of aminoglycoside antibiotics in sensory hair cells. Brain Res. 777:75-85, 1977.

Hashino E, Shero M, SAlvi RJ. In vivo and in vitro assessment of lysosomal activity during kanamycin uptake in hair cells. Assoc. Res. Otolanygol. Abstr. 24:240, 1998.

Hashino E, Shero M, Salvi RJ. Lysosomal augmentation during aminoglycoside uptake in cochlear hair cells. Brain Res. 887:9097, 2000.

Hawkins Jr JE, Johnsson LG, Aran JM. Comparative tests of gentamicin ototoxicity. J. Infect. Dis. 119:417-431, 1969.

Hirose K, Hockenbery DM, Rubel EW. Reactive oxygen species in chick hair cells after gentamicin exposure in vitro. Hear. Res. 104:1-14, 1997.

Hirose K, Westrum LE, Stone JS, Zirpel L, Rubel EW. Dynamic studies of ototoxicity in mature avian auditory epithelium. Ann. NY Acad. Sci. 884:389-409, 1999.

Howard M, Frizzell RA, Bedwell DM. Aminoglycoside antibiotics restore CFTR function by overcoming premature stop mutations. Nat. Med. 2:467-469, 1996.

Huang CJ, Favre I, Moczydlowski E. Permeation of large tetraalkylammonium cations through mutant and wild-type voltagegated sodium channels as revealed by relief of block at high voltage. J. Gen. Physiol. 115:435-454, 2000.

Hudspeth AJ. Extracellular current flow and the site of transduction by vertebrate hair cells. J. Neurosci. 2:1-10, 1982. 
Hudspeth AT, Kroese ABA. Voltage-dependent interaction of dihydrostreptomycin with the transduction channels in bullfrog sensory hair cells. J. Physiol. 345:66P, 1983.

Humes HD. Aminoglycoside nephrotoxicity [clinical conference]. Kidney Int. 33:900-911, 1988.

Humes HD. Insights into ototoxicity. Analogies to nephrotoxicity. Ann. NY Acad. Sci. 884:15-18, 1999.

ImAMURA SI, AdAms JC. Changes in Cytochemistry of sensory and nonsensory cells in gentamicin-treated cochleas. J. Assoc. Res. Otolaryngol. 4:196-218, 2003a.

Imamura SI, Adams JC. Distribution of gentamicin in the guinea pig inner ear after local or systemic application. J. Assoc. Res. Otolaryngol. 4:176-195, 2003b.

Khakh BS, Bao XR, Labarca C, Lester HA. Neuronal P2X transmitter-gated cation channels change their ion selectivity in seconds. Nat. Neurosci. 2:322-330, 1999.

Kroese AB, van den Bercken J. Effects of ototoxic antibiotics on sensory hair cell functioning. Hear Res. 6:183-197, 1982.

LERner SA, MATZ GJ. Suggestions for monitoring patients during treatment with aminoglycoside antibiotics. Otolaryngol. Head Neck Surg. 87:222-228, 1979.

Lewis ER, Leverenz EL, Bialek WS. The vertebrate inner ear. CRC Press, Boca Raton, FL, 1985.

Marche P, Olier B, Girard A, Fillastre JP, Morin JP. Aminoglycoside-induced alterations of phosphoinositide metabolism. Kidney Int. 31:59-64, 1987.

Marcotti W, Kros CJ. Dihydrostreptomycin is a permeant blocker of the outer hair cell transducer channel. Assoc. Res. Otolaryngol. Abstr. 25:602, 2002.

McLarnon S, Holden D, Ward D, Jones M, Elliott A, Riccardi D. Aminoglycoside antibiotics induce $\mathrm{pH}$-sensitive activation of the calcium-sensing receptor. Biochem. Biophys. Res. Commun. 297:71-77, 2002.

Meyers JR, MacDonald RB, Duggan A, Lenzi D, Standaret DG, Corwin JT, Corey DP. Lighting up the senses: FM1-43 loading of sensory cells through nonselective ion channels. J. Neurosci. 23:4054-4065, 2003.

Miller JJ. Handbook of ototoxicity. CRC Press, Boca Raton, FL, 1985.

Moestrup SK, Cui S, Vorum H, Bregengard C, Bjorn SE, Norris K, Gliemann J, Christensen EI. Evidence that epithelial glycoprotein $330 /$ megalin mediates uptake of polybasic drugs. J. Clin. Invest. 96:1404-1413, 1995.

MOLITORIs BA. Cell biology of aminoglycoside nephrotoxicity: newer aspects. Curr. Opin. Nephrol. Hypertens. 6:384-388, 1997.

Nassberger L, Bergstrand A, DePierre JW. Intracellular distribution of gentamicin within the rat kidney cortex: a cell fractionation study. Exp. Mol. Pathol. 52:212-220, 1990.

PAwLEY JB. Handbook of biological confocal microscopy, 3rd ed Plenum Press, New York, 1983.

Richardson GP, Russell IJ, Wasserkort R, Hans M. Aminoglycoside antibiotics and lectins cause irreversible increases in the stiffness of cochlear hair-cell stereocilia. In: Wilson JP, Kemp DT (Eds.) Cochlear Mechanisms-Structure, Function and Models. Plenum Press, New York, pp 578-586, 1989.

SAndoval R, Leiser JJ, Molitoris BA. Aminoglycoside antibiotics traffic to the Golgi complex in LLC-PK1 cells. J. Am. Soc. Nephrol. 9:167-174, 1998.

SAndoval RM, Dunn KW, Molitoris BA. Gentamicin traffics rapidly and directly to the Golgi complex in LLC-PK(1) cells. Am. J. Physiol. Renal. Physiol. 279:F884-F890, 2000.

Sha SH, Sснаснт J. Formation of reactive oxygen species following bioactivation of gentamicin. Free Radic. Biol. Med. 26:341-347, 1999a.
SHA SH, Schacht J. Stimulation of free radical formation by aminoglycoside antibiotics. Hear. Res. 128:112-118, 1999b.

Staecker H, Kopke R, Malgrange B, Lefebvre P, Van de Water TR. NT-3 and/or BDNF therapy prevents loss of auditory neurons following loss of hair cells. Neuroreport 7:889-894, 1996.

Stanislawski L, Carreau JP, Pouchelet M, Chen ZH, Goldberg M. In vitro culture of human dental pulp cells: some aspects of cells emerging early from the explant. Clin. Oral Investig. 1:131-140, 1997.

Steyger PS. Ultrastructural and immunohistochemical studies of cytoskeletal features in the guinea pig organ of Corti. Ph.D. Thesis, Keele University, UK, 1991.

Steyger PS, Burton M, Hawkins JR, Schuff NR, Baird RA. Calbindin and parvalbumin are early markers of non-mitotically regenerating hair cells in the bullfrog vestibular otolith organs. Int. J. Dev. Neurosci. 15:417-432, 1977.

Steyger PS, Gillespie PG, Baird RA. Myosin Ibeta is located at tip link anchors in vestibular hair bundles. J. Neurosci. 18:4603$4615,1998$.

Sundin DP, Meyer C, Dahl R, Geerdes A, Sandoval R, Molitoris BA. Cellular mechanism of aminoglycoside tolerance in longterm gentamicin treatment. Am. J. Physiol. 272:C1309-C1318, 1997.

Sundin DP, SANdoval R, Molitoris BA. Gentamicin inhibits renal protein and phospholipid metabolism in rats: implications involving intracellular trafficking. J. Am. Soc. Nephrol. 12:114123, 2001.

Tabatabay CA, Young LH, D’Amico DJ, Kenyon KR. Immunocytochemical localization of gentamicin in the rabbit retina following intravitreal injection. Arch. Ophthalmol. 108:723-726, 1990.

Tachibana M, Morioka H, Machino M, Mizukoshi O. Binding sites of an aminoglycoside in the cochlea examined by immunocytochemistry. Histochemistry 83:237-240, 1985.

Tachibana M, Morioka H, Machino M, Amagai T, Mizukoshi O. Aminoglycoside binding sites in the cochlea as revealed by neomycin-gold labelling. Histochemistry 85:301-304, 1986.

Tran Ba Huy P, Manuel C, Meulemans A, Sterkers O, Amiel C. Pharmacokinetics of gentamicin in perilymph and endolymph of the rat as determined by radioimmunoassay. J Infect. Dis. 143:476-486, 1981.

Virginio C, MacKenzie A, Rassendren FA, North RA, Surprenant A. Pore dilation of neuronal P2X receptor channels. Nat. Neurosci. 2:315-321, 1999.

WALKER PD, BARRI Y, SHAH SV. Oxidant mechanisms in gentamicin nephrotoxicity. Ren. Fail. 21:433-442, 1999.

WARD DT, MCLARnon SJ, Riccardi D. Ammoglycosides increase intracellular calcium levels and ERK activity in proximal tubular OK cells expressing the extracellular calcium-sensing receptor. J. Am. Soc. Nephro 13:1481-1489, 2002.

Wedeen RP, Batuman V, Cheeks C, Marquet E, Sobel H. Transport of gentamicin in rat proximal tubule. Lab. Invest. 48:212-223, 1983.

Wersall J, Lundquist PG, BJorkroth B. Ototoxicity of gentamicin. J. Infect. Dis. 119:410-416, 1969.

Wilschanski M, Famini C, Blau H, Rivlin J, Augarten A, Avital A, Kerem B, Kerem E. A pilot study of the effect of gentamicin on nasal potential difference measurements in cystic fibrosis patients carrying stop mutations. Am. J. Respir. Crit. Care Med. 161:860-865, 2000.

Zsembery A, Jessner W, Sitter G, Spirli C, Strazzabosco M, Graf J. Correction of CFTR malfunction and stimulation of Ca-activated $\mathrm{Cl}$ channels restore $\mathrm{HCO} 3-$ secretion in cystic fibrosis bile ductular cells. Hepatology 35:95-104, 2002. 